\title{
UPAYA PEMANFAATAN HALAMAN RUMAH SEBAGAI LAHAN PERTANIAN BUDIDAYA TANAMAN UNTUK MENSEJAHTERAKAN MASYARAKAT PADA MASA COVID 19 DI KELURAHAN TELUK PINANG
}

\author{
ZULKIFLI ${ }^{1}$ \\ ${ }^{1}$ Jurusan Pertanian, Fakultas Pertanian, Universitas Islam Indragiri \\ 2Indragiri Hilir \\ Email: zulk9632@gmail.com
}

\begin{abstract}
The period of the COVID-19 pandemic forces everyone to stay at home to break the chain of spreading the virus. This condition does not necessarily make farmers unproductive. Various activities can be carried out, especially those that can support household food needs. One thing that can be done is gardening organic vegetables in the yard. The yard is an area of land around the house. Almost all houses have a yard or yard. Diverse plants that can be planted on the home page, namely vegetable plants, fences, fruit plants, medicinal plants and herbs, and flowers. If managed properly, this land can provide benefits for the owner. The method used is by way of discussion and interviews. From the results of the interview, it can be seen that the people in Teluk Pinang Village have limited land at the time of Covid -19 in the yard of the house, but there are only many varieties of bvelum so that they are only for consumption.
\end{abstract}

Keywords: Pandemic, Gardening, Yard, Profits

\begin{abstract}
Abstrak
Masa pandemi COVID-19 memaksa setiap orang untuk tinggal di rumah demi memutus mata rantai penyebaran virus. Kondisi ini tidak serta merta membuat para petani menjadi tidak produktif. Beragam aktivitas bisa dilakukan, khususnya yang bisa menopang kebutuhan pangan rumah tangga. Salah satu yang bisa dilakukan adalah berkebun sayuran organik di pekarangan rumah.Pekarangan merupakan suatu lahan yang berada di sekitar rumah. Hampir semua rumah memiliki pekarangan atau halaman. Beranekaragam tanaman yang dapat di tanam pada halaman rumah yaitu Tanaman Sayuran, Tanaman Pagar, Tanaman Buah, Tanaman Obat dan bumbu dapur,serta Bunga. Apabila dikelola dengan baik maka lahan ini dapat memberikan keuntungan bagi pemilik. Metode yang dilakukan yaitu dengan cara diskusi dan wawancara. Dari hasil wawancara tersebut dapat diketahui bahwa masyarakat di Kelurahan Teluk pinang dalam keterbatasan lahan yang ada pada masa covid -19 di halaman rumah sudah ada namun hanya saja bvelum banyak varietas sehingga hanya untuk konsumsi saja.
\end{abstract}

Kata kunci: Pandemi, Berkebun, pekarangan, Keuntungan 


\section{PENDAHULUAN}

Masa pandemi COVID-19 memaksa setiap orang untuk tinggal di rumah demi memutus mata rantai penyebaran virus. Kondisi ini tidak serta merta membuat para petani menjadi tidak produktif. Beragam aktivitas bisa dilakukan, khususnya yang bisa menopang kebutuhan pangan rumah tangga. Salah satu yang bisa dilakukan adalah berkebun sayuran organik di pekarangan rumah. Aspek terpenting dalam pemanfaatan halaman rumah ini adalah tanaman hasil dari bertani di halaman rumah dapat mensejahterakan masyarakat baik dari segi penggunaan pribadi (konsumsi ) maupun untuk produksi (penjualan). Dari hasil observasi dan wawancara dengan pihak-pihak terkait, dapat diketahui bahwa permasalahan utama petani dalam bertani di halaman rumah yaitu keterbatasan lahan yang ada dan juga jumlah panen yang terbatas serta varietas tanaman yang tidak beragam.

\section{TINJAUAN PUSTAKA}

\subsection{Profil Kelurahan Teluk Pinang}

Kelurahan Teluk Pinang adalah salah satu kelurahan di kecamatan Gaung Anak Serka kabupaten Indragiri Hilir, Riau. Kelurahan Teluk Pinang merupakan Ibu Kota Kecamatan Gaung Anak Serka yang mayoritas penduduknya bermata pencaharian dalam bidang Pertanian, Perkebunan khususnya kebun kelapa dan perdagangan.

Daerah daratan merupakan wilayah perkebinan masyarakat yaitu jenis kelapa, pinang, dan sebagian sawit sebagian lagi masyarakat bercocok tanam dengan sistem perairan pasang surut dan tadah hujan serta bercocok tanam buah dan sayuran.

\subsection{Pertanian Halaman Rumah}

Pekarangan merupakan suatu lahan yang berada di sekitar rumah. Hampir semua rumah memiliki pekarangan. Pekarangan berfungsi sebagai pembatas lahan rumah dengan lahan lain baik lahan milik orang lain maupun lahan sendiri yang digunakan untuk keperluan lain (misal kebun). Nilai ekonomis berkaitan dengan kemampuan lahan pekarangan untuk menghasilkan tambahan pendapatan bagi pemilik misal dengan ditanami tanaman hortikultura (buah dan sayuran) dan budidaya ternak, unggas atau ikan.

Pemanfaatan pekarangan yang baik dapat mendatangkan berbagai manfaat antara lain yaitu sebagai warung, apotek, lumbung hidup dan bank hidup (Ashari dkk 2012). Disebut lumbung hidup karena sewaktu-waktu kebutuhan pangan pokok seperti jagung, umbiumbian dan sebagainya tersedia di pekarangan.Selain pekarangan difungsikan untuk pemenuhan bahan pangan (Arifin dkk. 2007), pekarangan untuk konservasi keanekaragaman hayati pertanian dapat juga mendukung agroekologi dan pertanian yang keberlanjutan (Marshall dan Moonen 2002).

Budidaya pekarangan tidak hanya dilakukan secara monokultur (satu jenis komoditas) namun bisa pula secara polikultur (beragam jenis komoditas). Pilihan tersebut disesuaikan dengan kemampuan dan keterampilan suatu keluarga.

2.3 Keaneka ragaman tanaman yang menguntungkan untuk pertanian halaman rumah

\subsubsection{Tanaman Sayuran}

Lahan pekarangan yang kosong dapat ditanami dengan berbagai komoditas pertanian. Komoditas hortikultur yang umum ditanam di pekarangan adalah berbagai macam sayuran. Jenis sayuran yang dapat ditanam adalah sayuran kangkung, bayam, selada, cabai, sawi dan lain-lain. Hasil panen sayuran diutamakan untuk memenuhi kebutuhan keluarga dulu. Apabila ada lebih maka bisa dijual sehingga pendapatan keluarga bertambah. 


\subsubsection{Tanaman Pagar}

Tanaman pagar disebut juga pagar hidup, maksudnya pagar yang sengaja dibuat dari tanaman. Tanaman pagar dipilih dari jenis yang dapat dimanfaatkan oleh pemilik. Beberapa tanaman yang sering dijadikan sebagai pagar adalah tanaman mangkokan, puring, petai cina, singkong, puring dan lain-lain. Bagian tanaman ini bisa dimanfaatkan sebagai sayuran, obatobatan maupun bahan bangunan. Selain bisa pemilik bisa memperoleh pendapatan, tanaman ini bisa juga dijadikan penghias rumah yang indah.

\subsubsection{Tanaman Buah}

Tanaman buahan merupakan salah satu tanaman yang umum ditanam di lahan pekarangan. Tanaman ini dimaksudkan sebagai penghasil buah yang akan dikonsumsi untuk keluarga maupun untuk tujuan komersial. Tanaman buah yang tinggi dan rindang biasanya juga dimaksudkan sebagai peneduh dan pelindung rumah dari cahaya matahari. Buah-buahan yang umum ditanam adalah jambu, jeruk, rambutan, pisang, mangga, strawberi dan lain-lain.

\subsubsection{Tanaman Obat dan bumbu dapur}

Masa kini, paradigma masyarakat berubah menjadi back to nature atau kembali ke alam. Lahgan pekarangan juga bisa dimanfaatkan untuk ditanami tanaman obat. Tanaman ini sangat bermanfaat untuk pengobatan tradisional dan sebagai salah satu bumbu dapur. Tanaman obat yang bisa ditanam di sekitar rumah adalah kunyit, sereh, kencur, mahkota dewa, tapak dara, kumis kucing dan lain-lain.

\subsubsection{Bunga}

Bunga ditanam untuk
mempercantik pekarangan rumah. Apabila rumah terlihat asri dan nyaman maka anggota keluarga pun akan memperoleh manfaat secara rohani.

\section{METODOLOGI PENELITIAN}

Wawancara Dalam penulisan ini,
peneliti menggunakan metode

wawancara dengan pedoman umum untuk mengumpulkan data dari subjek. Diskusi dilakukan kepada masyarakat dan petani di kelurahan Teluk Pinang ketika metode wawancara telah di laksanakan.

\section{HASIL DAN PEMBAHASAN}

\subsection{Kebijakan}

Masyarakat serta petani harus berinisiatif untuk memutus rantai covid 19 dengan melakukan aktifitas bertani di halaman rumah.

\subsection{Strategi}

Memberikan edukasi atau alternatif kepada masyarakat serta petani untuk bertani di halaman rumah sebagai alternatif bertani pada masa covid 19 .

\subsection{Upaya}

Berharap agar alternatif bertani di halaman rumah mampu membuat masyarakat mendapatkan keuntungan baik sebagai konsumsi maupun penjualan pada masa covid 19.

\subsection{Alternative Pemecahan Masalah 4.4.1. Subjek}

Adapun subjek dari penelitian ini adalah para petani serta warga yang ada di kelurahan Teluk pinang kecamatan Gaung Anak Serka kabupaten Indragiri Hilir.

\subsubsection{Objek}

Yang menjadi objek penelitian ini adalah bagaimana cara petani dan masyarakat umum di kelurahan teluk pinang mampu untuk memiliki hasil pangan karena pandemi covid-19 yang membuat masyarakat kurang melakukan aktifitas seperti biasanya dan mampu memiliki hasil dari bertani di halaman rumah sendiri baik untuk konsumsi maupun penjualan.

\section{Hasil dan kesimpulan wawancara dan diskusi}

Dari wawancara maka didapatkan hasil yaitu antara lain:

1. Keterbatasan lahan yang ada membuat warga enggan menanam tanaman di halaman rumah .

2. Karena lahan yang terbatas warga ada juga yang hanya menanam 1 
atau 2 tanaman sebagai konsumsi saja.

Dari hasil wawancara tersebut dapat diketahui bahwa masyarakat di Kelurahan Teluk pinang dalam keterbatasan lahan yang ada pada masa covid -19 di halaman rumah sudah ada namun hanya saja bvelum banyak varietas sehingga hanya untuk konsumsi saja.

Dalam diskusi peneliti memberikan gagasan dan pendapat mengenai bagaiamana peningkatan hasil dan varietas tanaman yang berbeda pada pertanian halaman rumah baik sebagai konsumsi mau pun penjualan.

Adapun materi diskusi yang dibahas antara lain:

1. Menyampaikan apa yang dimaksud pertanian halaman rumah

2. Menjelaskan bagaimana bisa pertanian halaman rumah mampu meberikan hasil serta sebagai alternatif pertanian di masa covid 19

\section{KESIMPULAN DAN SARAN}

\subsection{Kesimpulan}

Pertanian halaman rumah memiliki potensi sebagai salah satu lahan pertanian mini yang dapat dimanfaatkan untuk memenuhi kebutuhan rumah tangga (keluarga) itu sendiri apalagi pada masa covid 19 ini yang mana segala aktifitas di luar rumah dikurangi oleh pemerintah.

Budidaya ini dilakukan dalam skala kecil dan diutamakan untuk memenuhi kebutuhan rumah tangga. Produksi sendiri akan mengurangi pengeluaran rumah tangga sehingga dana yang sebelumnya ditujukan untuk kebutuhan sayur atau buah dapat dialihkan untuk memenuhi kebutuhan lain atau ditabung. Apabila ada kelebihan maka hasil panen bisa dijual. Bahkan bila budidaya di pekarangan ini berhasil maka bisa dikembangkan lebih lanjut untuk tujuan komersial.

Teknologi budidaya yang digunakan bermacam-macam. Pemilihan teknologi budidaya disesuaikan dengan selera, kemampuan dan keuangan yang tersedia.
Teknologi yang dapat dipilih antara lain tradisional atau modern. Mari kita memanfaatkan pekarangan secara optimal.

\subsection{Saran}

Dari penelitian ini yang berupa wawancara dan diskusi, peniliti mengharapkan masyarakat atau petani terutama yang membudidayakan tanaman obat ini agar dapat memanfaatkan dan menggunakan peluang yang ada untuk meningkatkan kesehatan mereka.

Selain itu baik pemerintah desa atau kabupaten terus menambahkan sosialisasi kepada masyarakat mengenai kegunaan tanaman obat ini sehingga dapat mendukung kesehatan mereka dalam rangka membantu kehidupan mereka menjadi lebih baik.

\section{DAFTAR PUSTAKA}

[1] Arifin HS, Munandar A, Mugnisjah WQ, Budiarti T, Arifin NHS, Pramukanto P. 2007. Homestead Plot Survey on Java. Research Report. Department of Landscape Architecture \& Rural Development Institute (RDI) SeattleUSA.

[2] Ashari, Saptana dan Purwanti, TB. 2012. Potensi dan Prospek Pemanfaatan Lahan Pekarangan Untuk Mendukung Ketahanan Pangan. Forum Penelitian Agro Ekonomi. Volum 30 No 1 hal $13-30$

[3] Marshall EJP, Moonen AC. 2002. Field margins in northern Europe: their functions and interactions with agriculture. Agric Ecosyst Environ 89:5-21. 